\title{
Jacobs, D. (dir.). (2017). La forêt [serie de televisión]. Francia: Carma Films
}

\author{
Valeria Arévalos \\ Universidad de Buenos Aires \\ arevalosvaleria@gmail.com
}

La forêt o "El bosque", en español, dirigida por Delinda Jacobs (2017), es una miniserie francesa de seis capítulos que cuenta la historia de un pequeño pueblo rodeado de frondosos bosques y colinas, Ardennes, en donde la calma se ve interrumpida, en más de una ocasión, por la desaparición de jóvenes lugareñas. El conflicto principal explota cuando la muchacha de dieciséis años, Jennifer (Isis Guillaume), desaparece de un día a otro sin dejar rastros. En momentos previos, la joven llama a la profesora Eve Mendel (Alexia Barlier) pidiendo socorro y, tras un grito, se corta definitivamente la comunicación. Será la docente quien insista y encabece la búsqueda de la adolescente, en detrimento de las ansias de calma pueblerina (Fig. 1).

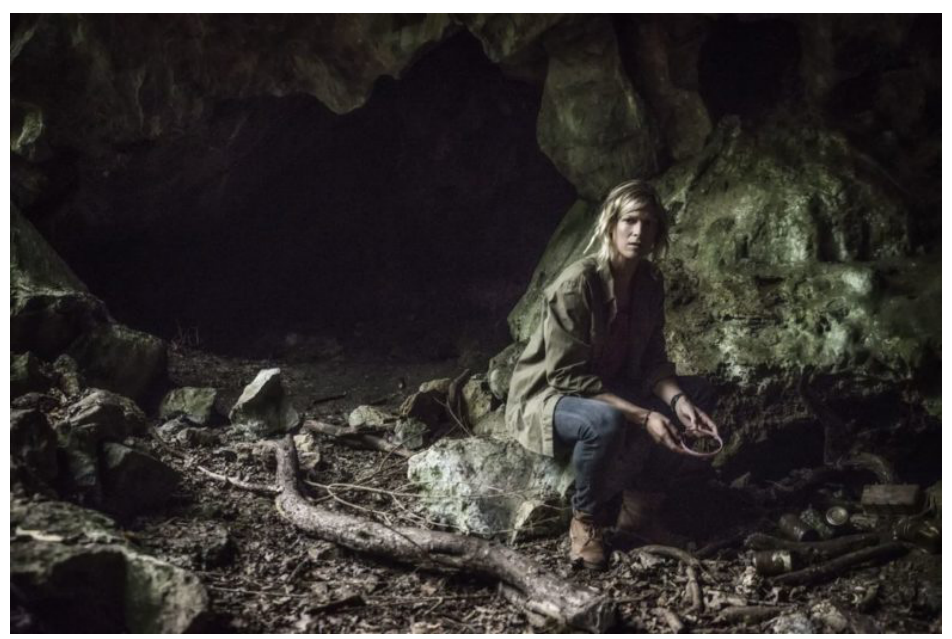

Figura 1: Fotograma de La Forêt, Eve Mendel.

En este primer acercamiento tenemos dos puntos interesantes para revisar. Por un lado, el título remite directamente al espacio en donde se suceden los crímenes. Y, por el otro, el personaje de Eve será fundamental para establecer un juego de polaridades de acecho entre el bosque y el pueblo. Lo que, al inicio, puede identificar al bosque como la oscuridad y el peligro, termina por invertirse mirando de frente al pueblo, de donde surgen los verdaderos cazadores. Con relación a este punto, una de las estrategias visuales más pregnantes de la serie es la de la manipulación del punto de vista. Constantemente estaremos detrás de una 
mirada invisible, que escudriña a los distintos personajes tratando de descubrir posibles culpables. Así es como la cámara, aún en planos fijos, será percibida a partir de un sutil movimiento equivalente al pulso de la mano que la sostiene. La estética de Jacobs podría dialogar con el trabajo de la fotógrafa británica Julia Margaret Cameron (1815-1879), quien, tras una particular búsqueda de la esencia de sus modelos, acuñó el término "foco suave" como aquel casi imperceptible movimiento que produce el alma atravesando al cuerpo del retratado. En este aspiracional de verdad, Cameron ya ponía en diálogo al movimiento con lo real. Lo fuera de foco, lo imperfecto. Jacobs acude a una estrategia similar en pos de exponer la auténtica esencia de sus personajes. La cámara los observa, se detiene, los recorre, intentando ir más allá de las palabras, hurgando en lo profundo del ser. Así, no será sólo en el bosque donde el espectador se pierda, sino en cada habitante de este pueblo que reniega de su pasado ominoso condenándose a repetir la misma pesadilla, una y otra vez.

Así como con la utilización del foco suave se devela la presencia del dispositivo cinematográfico (alguien sostiene la cámara, hay una instancia de mediación entre la imagen y el yo espectador), la utilización de los reflejos dará cuenta de la metaforización del alma en la puesta en escena. De este modo, por ejemplo, el personaje de Vincent, tras ser descubierto en sus mentiras, se verá desdoblado con su imagen reflejada en un espejo partido, dando cuenta de las múltiples facetas que irá desarrollando en el relato. Espejos, claros de agua, ventanas, servirán de juguetes ópticos con los que los habitantes de Ardennes se irán desnudando en sus distintas capas. El último plano, con una mirada limpia a cámara, estará asociado con la resolución de un misterio del pasado que llega a su fin.

El arte de los créditos expone esto último de una manera bella y, a la vez, nostálgica. Unas gotas de oscura tinta van manchando un lienzo claro hasta ir develando imágenes de la foresta, en una especie de doble exposición paulatina (Fig. 2). Asimismo, la narración se sirve de una importante cantidad de planos cenitales que describen el paisaje como un rincón hermoso e infranqueable al mismo tiempo. El reflejo del cielo en las aguas establece una suerte de trampantojo en donde todo se tergiversa, el arriba se verá abajo, el infierno estará en la superficie. La forêt no parece dejar nada librado al azar, destinando hacia los capítulos finales planos de cámara similares, pero con otro protagonista: el pueblo. Es ahí donde se esclarece el sentido de esta decisión, a medida que la resolución se acerca, la inversión en la mirada es evidente, posándose sobre el pueblo desde el bosque. Así, los árboles y las cuevas limitarán su rol a simples testigos de aquello que el hombre, que el pueblo, sacrifica y destruye.

En la cinematografía francesa existe otro claro ejemplo que toma la cuestión de la mirada y la problematiza desde la cámara: Caché, dirigida por Michael Haneke (2005). Allí, Georges Laurent (Daniel Auteuil) empieza a recibir videos de una extraña vigilancia hacia su hogar familiar. Sin otro recurso que la imagen, esa se- 


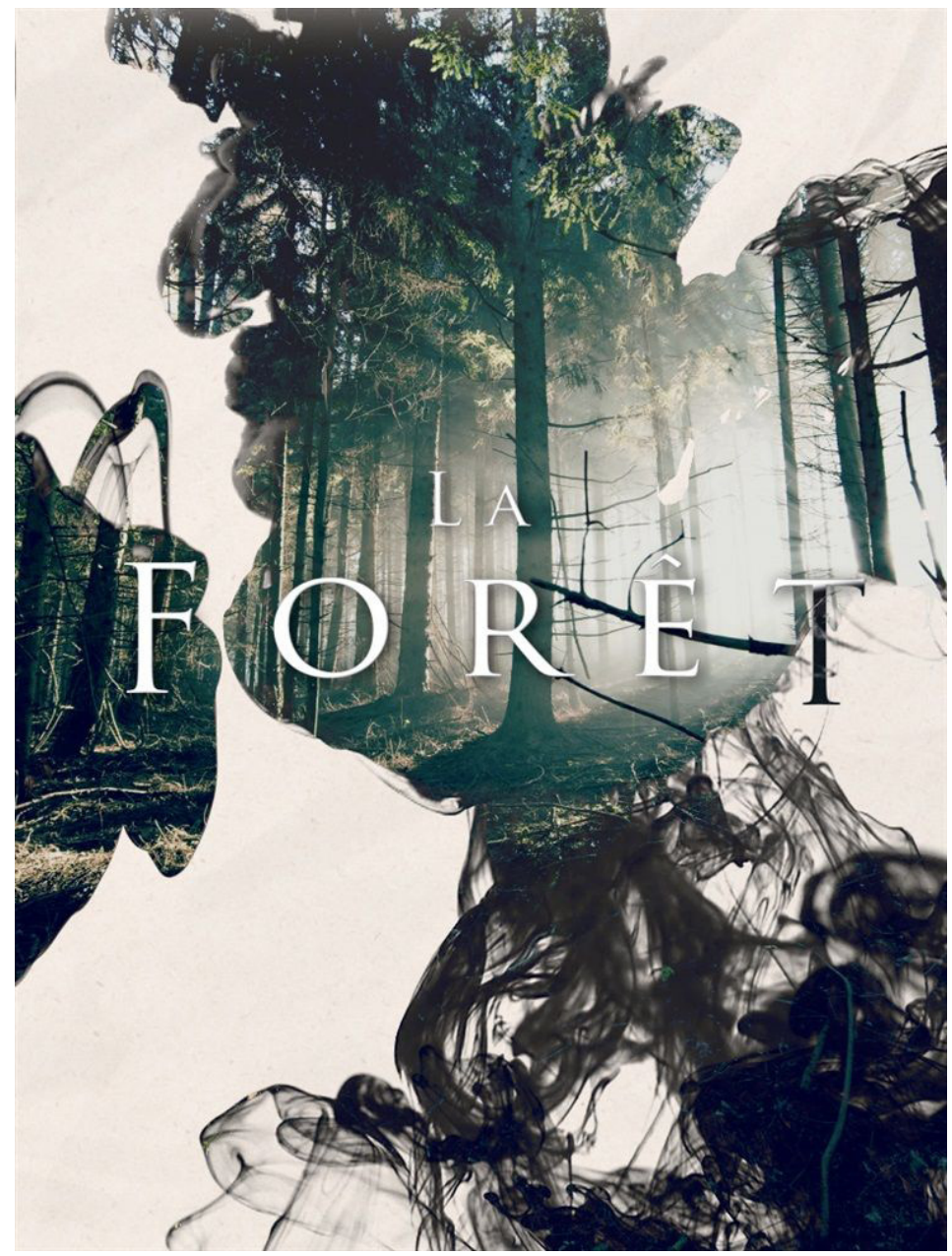

Figura 2: Créditos de La Forêt.

rie de videos bastará para despertar traumáticos recuerdos del pasado. Georges empezará a desandar un laberinto de silencios y decisiones, pero, lejos de buscar redención o de responsabilizarse por sus actos pretéritos, se reafirmará en la posición de héroe de la trama en busca de la eliminación definitiva del falso enemigo. Así como en Caché la situación de extrañamiento se daba por una constante vigilancia situada a la distancia, en La forêt nos encontramos con una mirada que no descansa y, desde lejos en ocasiones, casi desde demasiado cerca en otras, busca captar la esencia del sujeto. Éste se ve interpelado y desnudo, frente a la cámara, su falible humanidad. Los integrantes de esta comunidad caminan sobre charcos de secretos y silencios tratando de descubrir la paja en el ojo ajeno. 
El eje que vertebra la narración es el cuerpo femenino en la dinámica presenciaausencia, reflejada como conflicto principal con la desaparición de unas jóvenes en la insondable foresta lindera. Las mujeres ocupan los principales lugares de acción en el relato, siendo ellas las víctimas y también las heroínas, canalizadas principalmente en los personajes de la profesora Eve Mendel y la oficial de policía Virginie Musso (Suzanne Clement). Eve Mendel, como ya se mencionó, tomará las riendas del problema, dándole carácter de verdad al pedido de auxilio recibido por Jennifer previo a su desaparición. El personaje de Eve mantiene un diálogo intenso y profundo con el bosque; lo bucólico habita en ella otorgándole un saber místico y natural que la guiará tras las huellas de las jóvenes ausentes. Con el devenir de la trama se irá deshilvanando la historia de Mendel, que, lejos de estar desdibujada por el paso del tiempo, se va a ir exponiendo a la luz de los nuevos sucesos. Ella, veinte años atrás, fue una joven desaparecida más. La ausencia de Jennifer reforzará la presencia de Eve, canalizando el valor de las pistas, de los vacíos en los relatos, de lo no-dicho voluntariamente. El pueblo que las acoge será aquel que se silencia en torno al espectro desfigurado.

La mujer tratada como objeto desechable, como mera presencia efímera cuyo único fin es el cumplimiento del placer ajeno. La trata, la prostitución infantil, el ser devenido mercancía son, a la larga, los engranajes que dan movimiento a este grupo social que, amparado bajo la sombra de los árboles, funcionaba con una lógica particular, hasta que la desaparición de una chica en la actualidad y el interés de una mujer solidarizándose con esta ausencia, hizo caer los velos que cubrían de hipocresía y superficialidad a toda una comunidad.

La forêt va descubriendo el entramado turbio de una sociedad que desconoce a sus jóvenes, fetichiza a las mujeres y oculta los pecados bajo el tapete. 